\title{
TINJAUAN YURIDIS TERHADAP PENYELESAIAN DAMAI PERKARA SEDERHANA EKONOMI SYARIAH (ANALISIS KASUS DI PENGADILAN AGAMA KEDIRI)
}

\author{
Ahdiyat Ilmawan Nehru \\ Dian Berkah \\ Universitas Muhammadiyah Surabaya \\ Email : larosnehru@gmail.com
}

\begin{abstract}
The objective will be accomplished in the title of the thesis is the author of the above is to find out if the peace process is going on, and the proceedings conducted against a simple matter of Economics Sharia Religious Courts in Kediri were in accordance with the provisions of the law that applies.

This research uses the juridical normative approach i.e. researching secondary data or library material, then analyzed qualitative data analysis and results presented with descriptive method, namely by giving a picture in fact regarding the juridical review against a peaceful solution a simple matter of Economics Sharia Religious Courts in Kediri.

Based on the results of the research on settlement matters simple economics Sharia Religious Courts in Kediri via the litigation has been in accordance with the provisions of the applicable law, both at the stage of registration, ranging from up to judge drop the verdict. But against the occurrence of the verdict form peacekeeping assignment given by judges in future trials, is not the peace that occurs on the basis of the presence of both parties with the bond Act of peace, but rather the onset of peace because the judge grant the plaintiff's petition to revoke the matter, this occurs after the judge listened to the description of the plaintiff who stated upfront trial that the Defendants had completed his charge to the plaintiff. Besides that the consideration of judge of dikabulkannya petition for annulment of case filed by the Plaintiff because during the trial, the defendants never attend and sent his Deputy, so over the verdict ...
\end{abstract}

\section{Keywords : Sharia Economic Disputes, Peace, Trial}

\section{PENDAHULUAN}

Ekonomi merupakan salah satu aspek kehidupan yang sudah diatur dalam Islam sebagai agama yang sempurna maka mustahil apabila Islam tidak dilengkapi dengan sistem dan konsep ekonomi. QS. Al-Maidah ayat 3 :

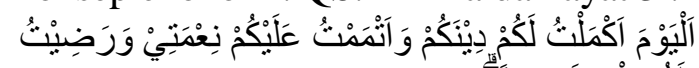

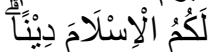

"pada hari ini telah Ku-sempurnakan untuk kamu agamamu dan telah Kucukupkan kepadamu nikmat-Ku dan telah Ku-ridhai Islam itu menjadi agama bagimu"1. Dalam Islam, perilaku individu maupun masyarakat dituntun melalui cara pemenuhan kebutuhan yang dilaksanakan sehari-hari serta bagaimana memanfaatkan sumber daya yang ada, sehingga aplikasi ekonomi dalam beragama sesuai dengan koridor-koridornya.

Ilmu Ekonomi Islam merupakan ilmu yang bertumpu pada sistem nilai dan prinsip syariah yang hakikatnya bisa memberikan makna dalam peran kehidupan manusia, sistem nilai tersebut mencakup pandangan dunia (khalaqiiyah), moral (khuluqiyyah), kemanusiaan (insaniyyah) dan berketuhanan

\footnotetext{
${ }^{1}$ Al-Qur'an QS. Al-Maidah ayat 3.
} 
(rabbaniyyah). Ilmu ekonomi islam /syariah mempunyai empat pilar filosofis :

Pilar pertama adalah tauhid. Tauhid bukan hanya tentang ajaran kepercayaan kepada tuhan yang maha esa, melainkan pengaturan sikap manusia terhadap tuhan dan seluruh sumber daya yang ada, baik sumber daya manusia maupun sumber daya alam. Manusia sebagai Khalifatullah, dalam bermuamalah harus senantiasa mengikuti ketentuan Allah, sehingga memounyai implikasi yang positif dalam sistem ekonomi seperti saling bekerja sama dalam meraih kemakmuran tanpa mengorbankan orang lain.

Pilar kedua adalah keadilan dan keseimbangan. Seluruh kebijakan dan kegiatan ekonomi harus berlandaskan pada pilar keadilan dan keseimbangan, yaitu dilaksanakan sesuai hukum-hukum dan ketentuan Allah, hal inilah yang harus diperjuangakan dalam kehidupan seharihari. Dalam ekonomi islam, keadilan dan keseimbangan tercermin dari terwujudnya pertumbuhan dan pemerataan ekonomi sehingga pembagian pendapatan dan kekayaan setiap orang tidak harus sama persis, diperbolehkan adanya perbedaan dalam pendapatan karena manusia diciptakan dan tersimpan dalam diri masingmasing watak, potensi dan pengabdiannya dalam menjalani sebuah kehidupan.

Landasan yang ketiga adalah kebebasan. Dalam hal ini kebebasan dalam menentukan sebuah keputusan yang berhubungan dengan kebutuhan hidup, karena dengan keputusan itulah manusia dapat menciptakan inovasi-inovasi yang baru dalam aktivitas yang berhubungan dengan ekonomi. Kreativitas manusia setiap individu berbeda-beda terutama dalam hal kegiatan ekonomi, banyak yang bisa dilakukan manusia dalam bertransaksi juga dalam memanajemen sebuah roda perekonomian. Walaupun demikian, kebebasan disini tetap dalam koridor yang nantinya akan dipertanggung jawabkan pribadi di hadapan Allah.

Landasan keempat yaitu tanggung jawab. Hubungan vertikal dan horizontal tetap melekat dalam pribadi masing-masing, seluruh aktivitaspun berkesinambungan dalam hal tanggung jawab. Sehingga tanggung jawab bukan hanya kepada manusia saja, melainkan tanggung jawab terberat adalah kepada Allah. Aspek sosial dari sebuah pertangung jawaban merupakan konsekuensi manusia sebagai khilafah yang bukan hanya secara spiritual, melainkan juga dalam kehidupan sehari-hari. Kesadaran dalam bertanggung jawab akan melahirkan kepedulian terhadap aturan-aturan yang perlu ditegakkan dalam kehidupan dan kesetiaan dalam melaksanakan dan memenuhi perintah allah yang tertuang dalam surat al-Baqarah ayat $177^{2}$ :

Kompetensi peradilan agama pada dasarnya secara historis sangat terpaut erat dengan pelaksanaan hukum Islam sebagai hukum yang hidup dimasyarakat, akan tetapi Indonesia bukan negara Islam sehingga kompetensi peradilan agama tidak menyangkut seluruh persoalan umat Islam melainkan hanya terkait dengan persoalan hukum keluarga (ahwal al-syakhsiyyah) dan ditambah beberapa persoalan muamalah.

Perubahan kompetensi mulai tampak dalam Undang-Undang No.1 Tahun 1974 yang meliputi perceraian, penentuan keabsahan anak, perwalian, penetapan asal usul anak, dan izin menikah. Sejak tahun 1989 kompetensi peradilan agama kembali mendapakan perluasan yaitu tentang masalah kewarisan, wasiat, hibah, wakaf dan sedekah dan ketentuan tersebut diatur dalam UndangUndang Nomor 7 Tahun 1989 tentang Peradilan Agama.

Pada tahun 2006 lahirlah UndangUndang Nomor 3 Tahun 2006 tentang

2 Amiur Nuruddin, 2010, Penyelesaian Sengketa Ekonomi Syariah dalam Perspektif Islam, hlm. 97. 
Kompetensi Peradilan Agama yang diperluas dengan memasukkan ekonomi syariah sebagai salah satu bidang kompetensinya, ruang lingkup kewenangan Peradilan Agama di bidang perbankan syari'ah, ini dapat dilihat dari penjelasan pasal 49 huruf (i) UndangUndang Nomor 3 Tahun 2006, yaitu :

"Pengadilan Agama bertugas dan berwenang memeriksa, memutus dan menyelesaikan perkara di tingkat pertama antara orang-orang yang beragama Islam di bidang ekonomi syariah; "yang dimaksud dengan ekonomi syariah adalah perbuatan atau kegiatan usaha yang dilaksanakan menurut prinsip syariah antara lain meliputi: bank syariah; lembaga keuangan mikro syariah; asuransi syariah; reasuransi syariah; reksa dana syariah; obligasi syariah dan surat berharga berjangka menengah syariah; sekuritas syariah; pembiayaan syariah; pegadaian syariah; dana pensiun lembaga keuangan syariah; keuangan syariah dan; bisnis syariah; ${ }^{3}$.

Sejak berlakunya Undang-Undang Nomor 3 Tahun 2006 Tentang Perubahan atas Undang-Undang Nomor 7 Tahun 1987 Tentang Peradilan Agama yang kemudian perubahan kedua dengan Undang-Undang Nomor 50 Tahun 2009, maka Pengadilan Agama berwenang untuk mengadili sengketa ekonomi syariah yang meliputi kegiatan ekonomi umat Islam atau masyarakat yang menundukkan diri pada ekonomi syariah yang bersengketa dengan perbankan syariah atau lembaga ekonomi syariah lainnya;

Perluasan kewenangan Pengadilan Agama ini kemudian muncul beberapa regulasi, diantaranya Undang-Undang Nomor 21 Tahun 2008 Tentang perbankan syariah yang pada pasal 55 menyebutkan (1) penyelesaian sengketa perbankan syariah dilakukan oleh Pengadilan dalam lingkungan Peradilan Agama. (2) Dalam hal para pihak

\footnotetext{
${ }^{3}$ Pasal 49 huruf (i) Undang-Undang Nomor 3 Tahun 2006 tentang Peradilan Agama.
}

telah memperjanjikan penyelesaian sengketa selain sebagaimana dimaksud pada ayat (1) penyelesaian sengketa dilakukan sesuai dengan isi akad. (3) Penyelesaian sengketa sebagaimana pada dimaksud pada ayat (2) tidak boleh bertentangan dengan prinsip syariah.

Namun dalam penjelasan pasal 55 ayat (2) tersebut dijelaskan bahwa yang dimaksud dengan "Penyelesaian sengketa dilakukan sesuai dengan isi akad" adalah upaya sebagai berikut : a. Musyawarah, b. Mediasi perbankan, c. Melalui Basyarnas (Badan Arbritase Syariah Nasional) atau lembaga arbitrase lainya, dan/atau d. Melalui Pengadilan Dalam Lingkungan Peradilan Umum.

Dengan demikian, maka kewenangan Pengadilan Agama atas sengketa perbankan syariah sebagaimana tersebut dalam pasal 55 ayat (1) tersebut diatas dimentahkan kembali dengan penjelasan pasal 55 ayat (2) yang apabila sengketa tersebut tidak dapat diselesaikan secara non litigasi melalui musyawarah, mediasi dan basyarnas ${ }^{4}$, kemudian tidak ada kepastian apakah sengketa tersebut menjadi kewenangan Pengadilan Agama atau Pengadilan Umum.

Namun ketidakpastian tersebut dapat diselesaikan dengan lahirnya putusan Mahkamah Konstitusi Nomor 93/PUU$\mathrm{X} / 2012$ yang mempertegas kewenangan peradilan agama dalam menangani sengketa perbankan syariah secara litigasi. Putusan Mahkamah Konstitusi ini merupakan penghapusan atas gagasan Choice of Law dan Choice of Forum dalam hal penyelesaian sengketa ekonomi syariah dalam UndangUndang Nomor 21 Tahun 2008 tentang Perbankan Syariah, yang sebelumnya dalam Penjelasan Pasal 55 ayat (2) menyebutkan bahwa penyelesaian sengketa ekonomi syariah dapat dilakukan melalui musyawarah, mediasi, Peradilan Umum dan Peradilan

4 Pasal 55 ayat (1) dan (2) Undang-Undang Nomor 21 Tahun 2008 tentang Perbankan Syariah. 
Agama. Namun dengan putusan ini Mahkamah Konstitusi menegaskan bahwa penyelesaian sengketa ekonomi syariah merupakan kewenangan absolut dari Pengadilan Agama.

\section{METODE PENELITIAN}

\section{Jenis Penelitian}

Dalam bab ini penulis akan terlebih dahulu mengklasifikasikan antara metodologi penelitian dengan penelitian, yang mana menurut Cholid Narbuko metodologi penelitian adalah cara meluluskan sesuatu dengan menggunakan pikiran secara seksama untuk mencapai suatu tujuan. ${ }^{5}$

Sedangkan Penelitian adalah suatu kegiatan untuk mencari, mencatat, merumuskan, dan menganalisis sampai menyusun laporan. ${ }^{6}$ Penelitian yang berjudul "Tinjauan Yuridis Terhadap Penyelesaian Damai Perkara Sederhana Ekonomi Syariah (Analisis Kasus di Pengadilan Agama Kediri)" ini adalah penelitian yang bersifat deskriptif dengan jenis penelitian yuridis normatif yaitu mengkaji, menelaah aspek hukum yang mengacu pada norma-norma hukum yang terdapat pada perturan perundang-undangan hukum perdata, hukum Islam dan Peraturan Mahkamah Agung.

Penelitian hukum normatif adalah metode penelitian hukum yang dilakukan dengan meneliti bahan kepustakaan atau data sekunder belaka. ${ }^{7}$
Pendekatan dalam penelitian hukum ini adalah Statute Approach ${ }^{8}$ atau pendekatan perundang-undangan yang dipergunakan sebagai dasar penelitian yang kemudian ditelaah. Dari hasil telaah tersebut adalah suatu argument untuk memecahkan isu yang sedang dihadapi pasca lahirnya putusan Mahkamah Konstitusi Nomor: 93/PUU-X/2012. Penelitian normatif tentu harus menggunakan pendekatan perundang-undangan, karena yang akan diteliti adalah berbagai aturan hukum yang menjadi fokus sekaligus tema sentral suatu penelitian. $^{9}$

\section{Sumber Data Penelitian}

Dalam penelitian ini yang digunakan oleh penulis dalam penulisan tesis adalah penelitian hukum normatif atau penelitian kepustakaan (Liberary Research). Penelitian hukum normatif yang dilakukan dengan cara meneliti bahan pustaka atau data sekunder, baik bahan hukum primer, sekunder dan tersier.

1. Bahan Hukum Primer

Bahan Hukum Primer terdiri dari Peraturan Perundang-Undangan, catatan resmi atau risalah dalam pembuatan PerundangUndangan, Peraturan Mahkamah Agung serta putusan hakim. Dalam hal penulis menggunakan suatu
Cholid Narbuko, Abu Achmadi, 1997, Metodologi Penelitian, Bumi Pustaka, Jakarta, hlm 1.

${ }^{6}$ Ibid.

7 Soerjono Soekanto dan Sri Mahmudji, 2006, Penelitian Hukum Normatif suatu Tinjauan Singkat, Raja Grafindo Persada, Jakarta, hlm 13.

\footnotetext{
8 Peter Mahmud Marzuki, 2005, Penelitian Hukum, Kencana, Jakarta, hlm 93-96.

9 Johny Ibrahim, 2005, Teori dan Metodologi Penelitian Hukum Normatif, Bayu Media, Malang, hlm 248.
} 
penelitian bahan hukum primer antara lain :

a. Undang-Undang Dasar Negara Republik Indonesia Tahun 1945, Pasal 1 ayat (3), dan Pasal 24 ayat (2).

b. Undang-Undang Republik Indonesia Nomor 30 Tahun 1999 Tentang Arbitrase dan Alternative Penyelesaian Sengketa.

c. Undang-Undang Republik Indonesia Nomor 3 Tahun 2006 Tentang Perubahan Atas Undang-Undang Nomor 7 Tahun 1989 Tentang Peradilan Agama.

d. Undang-Undang Republik Indonesia Nomor 21 Tahun 2008 Tentang Perbankan Syariah (Lembaran Negara Republik Indonesia Tahun 2008 Nomor 94).

e. Undang-Undang Republik Indonesia Nomor 48 Tahun 2009 Tentang Kekuasaan Kehakiman.

f. Undang-Undang Republik Indonesia Nomor 50 Tahun 2009 Tentang Perubahan Kedua atas Undang-Undang Nomor 7 Tahun 1989 Tentang Peradilan Agama.

g. Putusan Mahkamah Konstitusi Nomor 93/PUU$\mathrm{X} / 2012$.

h. Peraturan Mahkamah Agung Nomor 14 Tahun 2016 Tentang Tata Cara Penyelesaian Perkara Ekonomi Syariah.

i. Peraturan Mahkamah Agung Nomor 2 Tahun 2015 Tentang Tata Cara Gugatan Sederhana. j. Lembar Penetapan Majelis Hakim Pengadilan Agama Kediri Nomor : 0191/Pdt.G/2019/PA.Kdr

Tentang Perkara Gugatan Sederhana Ekonomi Syariah.

2. Bahan Hukum Sekunder

Bahan hukum sekunder merupakan bahan hukum yang memberi penjelasan lebih lanjut mengenai bahan primer, berupa tulisan para ahli yang berhubungan dengan permasalahan yang diteliti, hasil penelitian hukum, hasil karya ilmiah, artikel, dokumen, makalah, majalah hukum dsb yang relevan dengan permasalahan dalam penelitian ini. Bahan hukum sekunder penulis dalam penelitian ini yaitu:

a. Buku teks berisi tentang prinsip dasar ilmu hukum dan pandangan klasik para sarjana, baik mengenai Rechteorie, buku yang berkaitan dengan perbankan syariah, akad syariah, sengketa ekonomi syariah, hukum perbankan dan ketentuan perbankan di Indonesia. Yang diantaranya :

1) Briefcase Book Edukasi Profesional Syariah Konsep dan Implementasi Bank Syariah.

2) Briefcase Book Edukasi Profesional Syariah Fatwa-Fatwa Ekonomi Syariah Kontemporer.

3) Penyelesaian Sengketa Ekonomi Syariah 
Penemuan dan Kaidah Hukum.

4) Penyelesaian Sengketa Ekonomi Syariah "Teori dan Praktik".

b. Bahan berupa artikel, makalah, jurnal dan hasil seminar yang berisikan materi kompetensi absolut Peradilan Agama dalam penyelesaian sengketa perbankan syariah serta tata cara penyelesaiannya, diantaranya :
1) Majalah Hukum varia peradilan edisi 394 tahun 2018.
2) Majalah Hukum varia peradilan edisi 395 tahun 2018. dsb

\section{Bahan Hukum Tersier}

$$
\begin{aligned}
& \text { Bahan hukum tersier } \\
& \text { yaitu bahan hukum yang } \\
& \text { memberikan petunjuk atau } \\
& \text { penjelasan terhadap bahan } \\
& \text { hukum premier dan bahan } \\
& \text { hukum sekunder seperti: } \\
& \text { Kamus hukum, bahan-bahan } \\
& \text { diluar yang relevan dan dapat } \\
& \text { dipergunakan untuk } \\
& \text { melengkapi data yang } \\
& \text { diperlukan dalam penelitian. }
\end{aligned}
$$

\section{Cara Pengumpulan Data}

Dalam pengumpulan data terdapat beberapa cara yaitu: Studi kepustakaan, pengamatan (observasi), wawancara

10 Bambang Sunggono, 1998, Metodologi Penelitian Hukum, Ghalia Indonesia, Jakarta, hlm 195. Sebagaimana dikutip dari Soerjono Soekanto dan Sri Mahmudji, 1990, Penelitian Hukum Normatif Suatu Tinjauan Singkat, Rajawali Press, Jakarta, hlm 41. (interview), dan daftar pertanyaan (kuisioner). ${ }^{11}$ Dalam penelitian ini, penulis mengumpulkan data dengan cara :

a. Data Sekunder

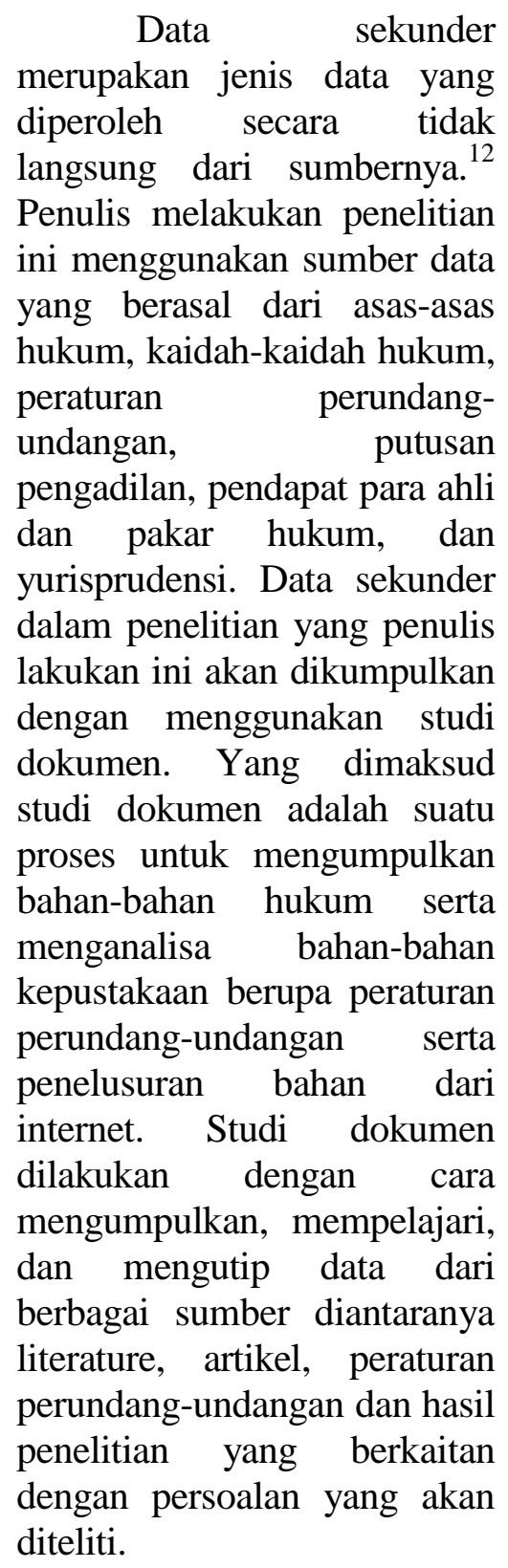

${ }^{11}$ Ronny Hanitijo Soemitro, 1994, Metode Penelitian Hukum dan Jurimetri, Ghalia Indonesia, Cetakan Kelima, Jakarta, hlm 12.

${ }^{12}$ Soerjono Soekanto dan Sri Mahmudji, 2001, Penelitian Hukum Normatif Suatu Tinjauan Singkat, Rajawali Press, Jakarta, hlm 14. 
b. Data Primer

Data primer di dalam penelitian yang penulis lakukan ini diperoleh langsung dari hasil penelitian dengan menggunakan metode wawancara (interview) kepada narasumber sebagai bahan pelengkap data sekunder. Wawancara adalah salah satu cara dalam mencari data dengan memberikan pertanyaan secara langsung dengan lisan kepada subyek penelitian, diantaranya :

1) Wawancara dengan Wakil Ketua Pengadilan Agama Kediri Bapak Drs. Abdul Rosyid, M.H.

2) Wawancara dengan Panitera Pengadilan Agama Kediri Bapak H. Hadiyatullah, S.H., M.H.

\section{Alat Pengumpulan Data}

a. Data Sekunder

Data sekunder dapat diperoleh dengan cara studi dokumen yaitu berupa bahan-bahan hukum primer, sekunder dan tersier agar penulis mengetahui dan kemudian mendeskripsikan dokumen terkait dengan focus penelitian.

\section{b. Data Primer}

Dalam pengumpulan data primer, alat yang digunakan berupa pedoman wawancara. Dan pedoman wawancara yang digunakan dalam penelitian ini adalah pedoman wawancara non terstruktur yaitu suatu pedoman yang memuat pertanyaanpertanyaan yang akan digunakan sebagai panduan dalam melakukan tanya jawab dengan narasumber.

\section{Instrumen Penelitian}

Instrumen Penelitian ini ialah narasumber yang terkait dengan rangkaian fakta yang akan diberitakan yang dimintai keterangan dan pernyataan atau orang yang sangat memahami fakta dari aspek teoritis. ${ }^{13}$ Dalam penelitian ini narasumber yang penulis temui adalah Wakil Ketua Pengadilan Agama Kediri Bapak Drs. Abdul Rasyid, S.H., M.H dengan Panitera Pengadilan Agama Kediri Bapak H. Hadiyatullah, S.H., M.H yang saat itu menyidangkan perkara sederhana sengketa ekonomi syariah dengan nomor perkara 0191/Pdt.G/2019/PA.Kdr.

\section{Teknis Analisis Data}

Data yang diperoleh kemudian dianalisis dengan menggunakan analisis deskriptif kualitatif, yaitu data yang berhasil dikumpulkan, dipilih menurut urutan yang berkualitas dan berkaitan dengan penelitian tersebut, dan diinventarisasi, diklarifikasikan menjadi data kualitatif untuk mendapatkan deskripsi yang jelas dan menyeluruh terhadap objek penelitian serta dipaparkan dan kemudian dianalisis untuk menginterpretasikan hukum yang berlaku, sehingga diperoleh jawaban atas permasalahan yang diajukan.

Analisis data ini menggunakan interpretasi atau penafsiran Teologis atau Sosiologis. Metode interpretasi teologis ini digunakan apabila pemaknaan suatu aturan hukum

13 Burhan Ash-Shofa, 2004, Metode Penelitian Hukum, PT. Rineka Cipta, Cetakan Keempat, Jakarta, hlm 22. 
ditafsirkan berdasarkan tujuan pembuatan aturan hukum tersebut dan apa yang ingin dicapai dalam masyarakat, dengan interpretasi teologis tersebut, penerapan aturan hukum yang sudah usang dan tidak cocok dengan kondisi masyarakat sekarang dapat disesuaikan dengan hubungan dan situasi sosial yang baru pada peristiwa hubungan hukum, kebutuhan, dan kepentingan para pencari keadilan. ${ }^{14}$

\section{HASIL DAN PEMBAHASAN}

\section{Gambaran Umum Obyek Penelitian}

Pengadilan Agama Kediri terletak di jantung kota Kediri yang beralamatkan di Jalan Sunan Ampel No 1, Desa Ngronggo, Kecamatan Kota Kediri, Kota Kediri. Pengadilan Agama Kediri adalah Pengadilan Agama kelas I $B$ yang menangani perkara cukup banyak setiap tahunnya kurang lebih 800-1500 perkara. Dengan terbatasnya Sumber Daya Manusia yang dimiliki, Pengadilan Agama Kediri terus berkomitmen untuk melayani para pencari keadilan dengan pelayanan yang prima, efektif dan efisien. Saat ini Pengadilan Agama Kediri hanya memiliki 4 (empat) orang hakim dalam menangani seluruh perkara yang terdaftar di kepaniteraan Pengadilan Agama Kediri, dengan dibantu oleh 1 (satu) orang Panitera, dan 5 (lima) orang Panitera Pengganti.

Sejak lahirnya UndangUndang Nomor 3 Tahun 2006 perubahan atas Undang-Undang Nomor 7 Tahun 1989 tentang kompetensi absolut Pengadilan
Agama, dapat mempermudah masyarakat dalam memilih penyelesaian sengketa ekonomi syariah, hal tersebut tertuang dalam pasal 49 huruf (i) yang berbunyi : Pengadilan Agama bertugas dan berwenang memeriksa, memutus, dan menyelesaikan perkara di tingkat pertama antara orang-orang yang beragama Islam di bidang" diantaranya Ekonomi Syariah.

Kewenangan absolut Pengadilan Agama tersebut juga telah ditegaskan dalam UndangUndang Nomor 48 Tahun 2009 tentang Kekuasaan Kehakiman. Dengan disahkannya UndangUndang Nomor 21 Tahun 2008 tentang Perbankan Syariah yang pada prinsipnya merupakan payung hukum lembaga perbankan syariah di dalamnya mengatur mengenai kewenangan penyelesaian sengketa yang terdapat dalam pasal 55 yang bunyinya :

1. Penyelesaian sengketa Perbankan Syariah dilakukan oleh Pengadilan dalam lingkungan Peradilan Agama.

2. Dalam hal para pihak telah memperjanjikan penyelesaian sengketa selain sebagaimana dimaksud pada ayat (1), penyelesaian sengketa dilakukan sesuai dengan isi akad.

3. Penyelesaian sengketa sebagaimana dimaksud pada ayat (2) tidak boleh bertentangan dengan prinsip syariah.

Pengadilan Agama Kediri telah melaksanakan amanah Undang-Undang Nomor 3 Tahun 2006 tentang sengketa ekonomi

${ }^{14}$ Ibid, hlm 222. 
syariah, yang mana Pengadilan Agama Kediri telah menerima dan memutus perkara sederhana sengketa ekonomi syariah yang nilainya kurang dari Rp. 200.000.000 (dua ratus juta rupiah) dengan putusan damai. Oleh karena itu penulis tertarik untuk melakukan penelitian dalam perkara sederhana ekonomi syariah di Pengadilan Agama Kediri ini dikarenakan perkara tersebut putus dengan terjadinya perdamaian.

\section{Penyajian Data}

a. Perdamaian yang Terjadi Antara Kedua Belah Pihak yang Bersengketa

Terhadap Perkara Sederhana Ekonomi Syariah di Pengadilan Agama Kediri Nomor Perkara:

0191/Pdt.G/2019/PA.Kdr.

Perkara gugatan sederhana sengketa ekonomi syariah, pada aspek-aspek tertentu justru mewajibkan hakim berperan aktif didalam persidangan.

Namun demikian bukan berarti pemeriksaan perkara sederhana sengketa ekonomi syariah telah keluar dari prinsip umum yakni hakim haruslah pasif. Maksud dari peran aktif hakim dalam gugatan sederhana sengketa ekonomi syariah, hanya diberikan pada hal-hal tertentu yang bersifat limitatife. Yakni seorang hakim haruslah aktif dalam membantu para pencari keadilan, dan berusaha mengatasi hambatan dan rintangan untuk dapat tercapainya peradilan yang sederhana, cepat dan biaya ringan. Hal tersebut telah diamanatkan dalam UndangUndang Nomor 48 Tahun 2009 tentang Kekuasaan Kehakiman.

Dalam menyelesaikan gugatan sederhana sengketa ekonomi syariah, peran aktif hakim telah diatur secara limitatife melalui Peraturan Mahkamah Agung Nomor 14 Tahun 2016. Peraturan tersebut dimaksudkan agar hakim memahami hal-hal apa saja yang membuat hakim harus bersifat aktif, yakni dalam hal sebagai berikut:

1. Hakim haruslah aktif dalam memberikan penjelasan mengenai tata cara gugatan sederhana sengketa ekonomi syariah secara berimbang kepada para pihak.

2. Hakim mengupayakan penyelesaian perkara sederhana sengketa ekonomi syariah secara damai, termasuk menyarankan agar supaya pihak-pihak dapat menyelesaikan sengketa ekonomi syariah diluar persidangan.

Dalam perkara sederhana sengketa ekonomi syariah tidak diberlakukan prosedur tentang mediasi, seperti yang dijelaskan dalam Peraturan Mahkamah Agung Nomor 1 Tahun 2016. 
Sehingga tidaklah wajib perkara sederhana sengketa ekonomi syariah menerapkan hal tersebut karena hanya merupakan pengecualian (lexspecialist). Tanggung jawab dalam mengupayakan perdamaian dikembalikan kepada masing-masing hakim pemeriksa perkara sebagaimana dimaksud oleh pasal $130 \mathrm{HIR} / 154 \mathrm{RBg}$.

Jika dalam sidang perkara sederhana sengketa ekonomi syariah terjadi perdamaian, maka hakim membuat putusan akta perdamaian yang mengikat para pihak, dan terhadap penetapan akta perdamaian dimaksud tidak dapat diajukan upaya hukum apapaun. Dan apabila perdamaian terjadi diluar persidangan maka para pihak harus memberikan laporan kepada hakim yang menyidangkan, dan apabila ternyata para pihak tidak memberikan laporan kepada hakim yang menyidangkan, maka hakim tersebut tidak terikat dengan perdamaian yang terjadi. Oleh karena itu, hakim hanya dapat menguatkan kesepakatan perdamaian di luar persidangan yang dilaporkan, atau di dalam persidangan dalam bentuk akta perdamaian.

Dari pembahasan diatas dan dengan hasil penelitian dilocus yang penulis pilih, peran aktif hakim di Pengadilan Agama
Kediri telah dilaksanakan dengan baik di saat persidangan berlangsung, sesuai dengan Peraturan Mahkamah Agung Nomor 14 Tahun 2016 tentang gugatan sederhana, yaitu memberikan nasehat kepada Penggugat untuk melakukan perdamaian dengan Tergugat atas sengketa ekonomi syariah yang Penggugat ajukan. Termasuk memberikan nasehat agar supaya para pihak dapat menyelesaikan sengketa ekonomi syariah diluar persidangan. ${ }^{15}$

Dalam hal terjadinya kesepakatan damai diluar persidangan perkara sederhana sengketa ekonomi syariah di Pengadilan Agama Kediri, hakim tidak dapat menguatkan perdamaian tersebut dengan menerbitkan akta perdamaian, dikarenakan tidak terpenuhinya syarat perdamaian yakni para pihak yang bersengketa harus melaporkan kepada hakim. Sehingga menurut hemat penulis sesuai dengan isi amar putusan dalam perkara sederhana sengketa ekonomi syariah di Pengadilan Agama Kediri, apa yang telah diputuskan hakim terkait permohonan pencabutan perkara penggugat sudahlah tepat dan dapat diartikan telah terjadi perdamaian, meski putusan hakim yang

\footnotetext{
15 Wawancara dengan Abdul Rosyid, Ketua Pengadilan Agama Kediri Pada Tanggal 17 Mei 2019, di Kediri
} 
mengabulkan permohonan pencabutan perkara tersebut didasarkan atas keterangan sepihak dari Penggugat di persidangan yang menyatakan bahwa Tergugat telah menepati janjinya untuk melunasi semua kewajiban yang sempat tertunda sesuai perjanjian yang telah disepakatinya sejumlah Rp. 6.943.000,- (enam juta sembilan ratus empat puluh tiga rupiah).

Penulis juga sependapat dengan hakim yang mengambil langkah hukum yakni meskipun Tergugat tidak hadir, keterangan Penggugat tersebut tetap dijadikan dasar dalam pemeriksaan lebih lanjut sampai dengan perkara ini diputus, selain itu hakim juga tidak serta merta memutus perkara ini dengan perdamaian sebagaimana diatur dalam ketentuan pemeriksaan sidang perdamaian sebagaiman Pasal $15 \quad$ Peraturan Mahkamah Agung Nomor 2 Tahun 2015 Tentang Tata Cara Gugatan Sederhana yang pada intinya : "dalam hal tercapai perdamaian, maka Hakim membuat putusan akta perdamaian yang mengikat para pihak. Terhadap penetapan akta perdamaian dimaksud tidak dapat diajukan upaya hukum apapun".

Selain hal tersebut
hakim
memberikan

kepada Penggugat tanpa hadirnya Tergugat di Persidangan, meskipun tidak selaras dengan maksud ketentuan Pasal 14 Peraturan Mahkamah Agung Nomor 2 Tahun 2015 Tentang Tata Cara Gugatan Sederhana jo Pasal 14 huruf (b) Peraturan Mahkamah Agung Nomor 14 Tahun $2016 \quad$ Tentang Tatacara Penyelesaian Sengketa Ekonomi Syariah yang berbunyi sebagai berikut :

1. Memberikan penjelasan mengenai acara gugatan sederhana secara berimbang kepada para pihak;

2. Mengupayakan penyelesaian perkara secara damai termasuk menyarankan kepada para pihak untuk melakukan perdamaian diluar persidangan.

Dari hasil penelitian yang telah dijelaskan diatas, apa yang diputuskan hakim menurut penulis masih dalam tahap wajar dan tidak berlebihan, yang mana dalam gugatan perkara sederhana sengketa ekonomi syariah tersebut hakim memutus berdasarkan permohonan pencabutan perkara yang diajukan Penggugat dengan alasan Tergugat telah melunasi kewajiban terhadap perjanjian yang telah disepakati dan merugikan Penggugat sejumlah Rp. 
6.943.000,00,- yang dalam amarnya berbunyi :

1. Mengabulkan permohonan pencabutan perkara nomor: 0191/Pdt.G/2019/PA. Kdr oleh Penggugat;

2. Memerintahkan kepada Panitera untuk mencatat pencabutan perkara tersebut dalam register perkara;

3. Membebankan kepada Penggugat untuk membayar biaya perkara sejumlah Rp. 281.000,(dua ratus delapan puluh satu ribu rupiah);

Maka oleh karena itu dari seluruh pembahasan diatas tadi, menurut pendapat Penulis bahwa amar penetapan yang dijatuhkan hakim dalam perkara sederhana sengketa ekonomi syariah yang diajukan Penggugat adalah tepat dan telah sesuai dengan ketentuan hukum yang diatur dalam Buku II "Pedoman Pelaksanaan Tugas dan Administrasi Peradila Agama" Yang berbunyi: Pencabutan gugatan yang diajukan sebelum Tergugat memberikan jawaban tidak perlu minta persetujuan Tergugat. $^{16}$

Dalam hal mengenai waktu penyelesaian gugatan perkara sederhana sengketa ekonomi syariah yang

\footnotetext{
${ }^{16}$ Mahkamah Agung Republik Indonesia, 2014, Pedoman Pelaksanaan Tugas dan Administrasi Peradilan Agama Buku II, Jakarta, hlm 73
}

diajukan oleh Penggugat tanggal 12 Maret 2019 dan telah terdaftar di Kepaniteraan Pengadilan Agama Kediri Nomor 0191/Pdt.G/2019/PA.Kdr tanggal 13 Maret 2019 yang dalam proses persidangan hingga perkara tersebut diputus pada tanggal 28 Maret 2019, hal mana menurut perhitungan penulis perkara tersebut oleh Hakim telah diselesaikan dengan waktu 15 hari.

Jika dikaitkan dengan ketentuan Pasal 15 Peraturan Mahkamah Agung Nomor 2 Tahun 2015 Tentang Tata Cara Gugatan Sederhana bahwa penyelesaian gugatan sederhana sengketa ekonomi syariah paling lama 25 hari kerja sejak hari sidang pertama, maka dalam hal ini waktu yang digunakan Hakim masih jauh dari batas waktu yang ditentukan, sehingga karenanya menurut pendapat Penulis bahwa penetapan Hakim yang mengabulkan permohonan pencabutan gugatan sederhana sengketa ekonomi syariah pada Pengadilan Agama Kediri tersebut adalah tepat dan sesuai dengan ketentuan hukum yang berlaku.

Disisi lain terhadap sengketa ekonomi syariah yang didaftarkan di Pengadilan Agama Kediri melalui jalur litigasi bisa saja ditelaah dan di petakan terlebih dahulu sebelum 
memeriksa pokok perkara didalam isi gugatan yang diajukan, serta memberikan pemahaman kepada para pihak tentang jenis-jenis sengketa ekonomi syariah yang dapat diajukan, apakah penyelesaiannya melalui jalur litigasi atau jalur non litigasi, selain itu agar supaya para pihak yang bersengketa tidak dirugikan baik secara materi, pikiran maupun tenaga, karena hal tersebut juga sesuai dengan Visi dan Misi Mahkamah Agung Republik Indonesia yakni memberikan pelayanan yang prima, cepat, tepat dan biaya ringan. ${ }^{17}$ Bahwa menurut pendapat penulis perkara gugatan sederhana sengketa ekonomi syariah yang di daftarkan di kepaniteraan Pengadilan Agama Kediri dengan nomor perkara 0191/Pdt.G/2019/PA.Kdr, dan telah diputus oleh hakim tunggal Pengadilan Agama Kediri setelah penulis melakukan penelitian dan mengkomparasikan dengan kajian pustaka, gugatan sengketa ekonomi syariah tersebut bisa dikatakan sebagai sengketa non litigasi, yang mana terjadinya perdamaian antara kedua belah pihak merupakan bagian dari alternative penyelesaian sengketa (APS) atau yang dikenal dengan istilah Alternative Dispute

17 Mahkamah Agung Republik Indonesia, 2010, Cetak Biru Pembaruan Peradilan, Jakarta, hlm 30
Resolution (ADR), yaitu perdamaian yang terjadi di luar persidangan dengan menggunakan mekanisme musyawarah dan negosiasi. Bahwa menurut penulis sangatlah penting bagi seluruh stakeholder dan pemangku kepentingan di Pengadilan Agama Kediri untuk memahami asas-asas dan jenis-jenis gugatan sengketa ekonomi syariah beserta cara penyelesaiaanya, agar supaya masyarakat tidak terjebak dalam proses hukum yang samar atau tidak jelas, karena hal tersebut juga akan berdampak pada lembaga Peradilan kita sendiri, terlebih turunnya tingkat kepercayaan masyarakat kepada badan peradilan.

\section{b. Proses Persidangan Perkara Sederhana Sengketa Ekonomi Syariah di Pengadilan Agama Kediri Nomor : 0191/Pdt.G/2019/PA. Kdr}

Secara umum penerimaan perkara gugatan sederhana sengketa ekonomi syariah sama dengan perkara perdata lainnya yang menjadi kewenangan absolut Pengadilan Agama. Pertama, Penggugat menghadap seorang diri kepada petugas meja pendaftaran dengan membawa surat gugatan serta kartu tanda penduduk, setelah itu Panitera Pengadilan Agama Kediri mempelajari berkas gugatan yang diajukan oleh 
Penggugat tertanggal 12

Maret 2019 untuk

menentukan apakah isi

gugatan Penggugat termasuk

dalam gugatan sederhana

sengketa ekonomi syariah

atau tidak, setelah dipelajari

dan diteliti oleh Panitera, gugatan Penggugat diberi nomor register dikepaniteraan Pengadilan Agama Kediri dengan register perkara masuk gugatan sederhana sengketa ekonomi syariah nomor: 0191/Pdt.G/2019/PA. Kdr tanggal 13 Maret 2019, kemudian Penggugat diperintahkan untuk membayar panjar biaya perkara sesuai dengan radius tempat tinggal Penggugat dan Tergugat.

Selanjutnya hasil penelitian yang dilakukan Penulis di Pengadilan Agama Kediri, dapat diuraikan sebagai berikut di bawah ini:

a. Identitas Para Pihak

\begin{tabular}{lr}
\multicolumn{2}{c}{ Gugatan sederhana } \\
perkara ekonomi & syariah \\
diajukan kepada & Ketua \\
Pengadilan Agama & Kediri \\
tanggal 12 Maret 2019 oleh \\
Titis Prasetyo, agama Islam, \\
Pekerjaan Direktur PT. BPR \\
Syariah Tanmiya Artha, yang \\
bertempat tinggal di & Ruko \\
Brawijaya A-17 & Jalan \\
Brawijaya No. & 40, \\
Kecamatan Kota, Kota & Kotan \\
Kediri, melawan & pihak \\
Tergugat bernama Dwi Ratna
\end{tabular}

${ }^{18}$ Wawancara dengan Hadiyatullah, Panitera Pengadilan Agama Kediri Pada Tanggal 17 Mei 2019, di Kediri.
Wati, umur 32, agama Islam, pekerjaan wiraswasta, bertempat tinggal di jalan Margotani RT, 019 RW. 006 Kelurahan Sukorame Kecamatan Mojoroto, Kota Kediri. Yang terdaftar di kepaniteraan Pengadilan Agama Kediri dengan nomor pendaftaran 191/Pdt.G/2019/PA. Kdr, tanggal 13 Maret 2019.

\section{b. Posita (Dalil Gugatan)}

Penggugat

mengajukan gugatan sederhana perkara ekonomi syariah, dengan alasan Tergugat telah melakukan inkar janji terhadap perjanjian Murabahah Nomor 032/TAKDR/MBA/I/18, hari Rabu tanggal 24 Januari 2018, dengan isi perjanjian sebagai berikut :
1) Tergugat mengajukan pembiayaan kepada Penggugat untuk keperluan modal kerja sebesar Rp. 7.000.000,- (tujuh juta rupiah);

2) Harga jual disepakati sebesar Rp. 9.690.000,(Sembilan juta enam ratus sembilan puluh ribu rupiah);

3) Jangka waktu 24 bulan terhitung mulai 24 Januari 2018 sampai dengan 24 Januari 2020. Dan setiap bulan Tergugat berkewajiban membayar Rp. 404.000,- (empat ratus empat ribu rupiah) yang akan dibayar setiap tanggal 24 bulan berjalan. 
4) Tergugat menjaminkan satu unit kendaraan bermotor roda 2 beserta BPKB dengan spesifikasi sebagai berikut :
a) Nomor BPKB L- 11822131
b) Nopol AG 2308 CB
c) Merk Yamaha SE88
d) Tahun 2015
e) Warna Hitam
f) Atas nama SUPARTI
Dari yang

diperjanjikan tersebut di atas Tergugat melanggar perjanjian yaitu bahwa Tergugat tidak melaksanakan kewajiban membayar sesuai yang diperjanjikan dalam perjanjian Murabahah No. 032/TA-KDR/MBA/I/18

(wanprestasi).

Akibat dari tindakan

Tergugat tersebut, Penggugat menderita kerugian sebesar Rp. 6.464.000,- (enam juta empat ratus enam puluh empat ribu rupiah) ditambah denda keterlambatan sebesar Rp. 479.000,- (empat ratus tujuh puluh sembilan ribu rupiah) sehingga total kerugian Penggugat sebesar Rp. 6.943.000,- (enam juta sembilan ratus empat puluh tiga ribu rupiah).

Padahal Penggugat telah memberikan waktu dan peringatan yang cukup kepada Tergugat untuk menyelesaikan

kewajibannya. Dengan buktibukti surat sebagai berikut:

1) Perjanjian Mudharabah nomor: 032/TA-
KDR/MBA/I/18

ditandatangani pada hari Rabu tanggal 24 januari 2018

2) Catatan Pembayaran Tergugat, Tergugat tercatat membayar 8 kali angsuran dari $24 \quad$ kali angsuran yang menjadi kewajiban Tergugat.

3) Bukti surat peringatan :

a) Surat Peringatan I (pertama) No. 129/TA-

Kdr/MKT/X/18 tertanggal 08 Oktober 2018.

b) Surat Peringatan II (kedua) No. 139/TA$\mathrm{Kdr} / \mathrm{MKT} / \mathrm{X} / 18$ tertanggal 23 Oktober 2018.

c) Surat Peringatan III (ketiga) No. 141/TAKdr/MKT/XI/18 tertanggal $\quad 02$ Nopember 2018.

Selain bukti surat di atas di tambah bukti seorang saksi bernama Nafiudin, lahir di Jombang tanggal 20 Nopember 1991, berstatus sebagai petugas penagih kepada Tergugat dari PT BPR Syariah Tanmiya Artha yang beralamat di Jalan Joyosaban Rukun Tetangga 002 Rukun Warga 003 Dusun 
Gabus Desa Banaran Kecamatan Tembelang

Kabupaten Jombang.

c. Petitum (Yang dituntut)

Berdasarkan segala uraian yang telah dikemukakan di atas, Penggugat mohon kepada Ketua Pengadilan Agama Kediri untuk memanggil para pihak yang bersengketa pada persidangan yag telah ditentukan, guna memeriksa, mengadili dan memutus gugatan ini, dan selanjutnya berkenan memutus dengan amar sebagai berikut :

1) Menerima dan Mengabulkan gugatan Penggugat seluruhnya;

2) Menyatakan demi hukum perbuatan Tergugat Wanprestasi kepada Penggugat;

3) Menghukum Tergugat untuk melunasi seluruh kewajiban kepada Penggugat sebesar Rp. 6.943.000,- (enam juta sembilan ratus empat puluh tiga ribu rupiah), atau menyerahkan jaminan.

4) Menghukum Tergugat untuk membayar biaya perkara yang timbul.

Atau apabila

Pengadilan berpendapat lain mohon putusan yang seadiladilnya. Demikianlah gugatan ini saya ajukan, semoga Ketua Pengadilan Agama Kediri bekenan mengabulkanya.

\section{d. Proses Persidangan}

Setelah

Ketua

Pengadilan Agama Kediri menerbitkan Penetapan

Majelis Hakim (PMH) dengan Hakim tunggal, Panitera menunjuk Panitera Pengganti yang akan bersidang dan Jurusita Pengganti serta Ketua Majelis membuat Penetapan Hari Sidang (PHS), maka selanjutnya tahapan persidangan dilakukan sebagai berikut :

1) Sidang pertama dilaksanakan tanpa dihadiri Tergugat di persidangan, dan tidak pula menyuruh orang lain untuk menghadap sebagai wakilnya, meskipun ia telah dipanggil secara resmi dan patut, sedangkan ternyata bahwa ketidakhadiran Tergugat tersebut tidak disebabkan oleh suatu alasan yang sah.

2) Hakim telah menasehati Penggugat agar berusaha menyelesaikan permasalahannya dengan Tergugat melalui musyawarah.

3) Pada persidangan kedua Penggugat hadir di persidangan, sedangkan Tergugat tidak hadir dan tidak pula menyuruh orang lain untuk menghadap sebagai wakilnya, meskipun ia telah dipanggil secara resmi dan patut, sedangkan ternyata bahwa ketidakhadiran Tergugat tersebut tidak 
disebabkan oleh suatu alasan yang sah.

4) Penggugat di persidangan menyatakan bahwa Tergugat telah melunasi semua kewajiban yang sempat tertunda, dan dengan demikian maka Penggugat menyatakan mencabut gugatan ini karena Tegugat telah melunasi kewajibannya.

\section{e. Pertimbangan Hukum}

\begin{tabular}{lr}
\multicolumn{1}{c}{ Sebelum } & Hakim \\
menjatuhkan & penetapan, \\
maka terlebih & dahulu \\
mengemukakan & \\
pertimbangan & sebagai \\
berikut:
\end{tabular}

1. Majelis Hakim telah berhasil menasehati Penggugat untuk menyelesaikan sengketa perkara sederhana ekonomi syariah;

2. Sesuai keterangan Penggugat bahwa Tergugat telah melunasi semua kewajiban yang sempat tertunda, sehingga dengan demikian Tergugat telah menepati janjinya untuk melunasi semua sesuai perjanjian yang telah disepakati;

3. Penggugat menyatakan telah mencabut perkaranya tersebut karena Tergugat telah melunasi semua kewajibannya tersebut, berdasarkan Pasal $271 \mathrm{Rv}$, maka pencabutan
Penggugat

dikabulkan.

dapat

\section{f. Amar Putusan}

Berdasarkan

pertimbangan yang telah dikemukakan diatas Hakim menjatuhkan penetapan yang amarnya berbunyi sebagai berikut:

1) Mengabulkan permohonan pencabutan perkara Nomor:

0191/Pdt.G/2019/PA. Kdr oleh Penggugat;

2) Memerintahkan kepada Panitera untuk mencatat pencabutan perkara tersebut dalam register perkara;

3) Membebankan kepada Penggugat untuk membayar biaya perkara sejumlah Rp. 281.000,(dua ratus delapan puluh satu ribu rupiah). ${ }^{19}$

g. Tanggal Putusan

Perkara sederhana

ekonomi syariah yang diajukan pada tanggal 12 Maret 2019 dan terdaftar di Kepaniteraan Pengadilan Agama Kediri nomor 0191/Pdt.G/2019/PA. Kdr tanggal 13 Maret 2019 telah diputus pada hari kamis tanggal 28 Maret 2019 Masehi, bertepatan dengan tanggal 21 Rajab 1440 Hijriyah yang dihadiri pihak Penggugat tanpa hadirnya Tergugat.

h. Susunan Majelis Yang Bersidang

\footnotetext{
19 Penetapan Perkara Sederhana Sengketa Ekonomi Syariah Nomor Perkara 0191/Pdt.G/2019/PA. Kdr Tanggal 28 Maret 2019
} 


$$
\text { Perkara sengketa }
$$
sederhana ekonomi syariah ini disidangkan oleh Hakim Tunggal yang bernama Drs. Abdul Rosyid, M.H. dan didampingi oleh seorang Panitera Pengganti bernama Hartono, S.H.

Jika ditelaah dari formulir gugatan sederhana yang diajukan oleh Penggugat hingga proses persidangan dan perkara diputus telah tergambar bahwa Penggugat hadir dalam persidangan setelah menerima relaas panggilan yang disampaikan Jurusita Pengganti Pengadilan Agama Kediri dan Tergugat tidak hadir di persidangan meskipun telah dipanggil secara resmi dan patut, yang dalam hal ini penulis kemukakan dalam tahapan persidangan sebagai berikut:

1) Pemeriksaan Pendahuluan Sebelum pemeriksaan pokok gugatan Hakim yang ditunjuk untuk menyelesaikan perkara sederhana sengketa ekonomi syariah yang diajukan Penggugat terdaftar di Kepaniteraan Pengadilan Agama Kediri Nomor:

0191/Pdt.G/2019/PA. Kdr telah terlebih dahulu memeriksa materi gugatan sederhana dan sudah sesuai syarat sebagaimana yang diatur dalam Pasal 3 dan Pasal 4 Peraturan Mahkamah Agung Nomor
2 Tahun 2015 Tentang Tata Cara Gugatan Sederhana.

2) Penetapan Hari Sidang dan Pemanggilan Para Pihak

Selanjutnya Hakim Pengadilan Agama Kediri membuat penetapan hari sidang yang diantaranya berisi perintah Jurusita Pengganti untuk memanggil para pihak paling lambat 2 hari kerja sebelum hari sidang. Hal ini Concordan dengan bunyi pasal 20 ayat (2) Peraturan Mahkamah Agung Nomor 2 Tahun 2015.

3) Pemeriksaan Sidang dan Perdamaian

Hakim Pengadilan Agama Kediri telah berupaya menasehati Penggugat agar menyelesaikan perkaranya secara damai meskipun Tergugat tidak pernah hadir dalam persidangan, berdasarkan nasehat hakim tersebut Penggugat telah melakukan kesepakatan damai dengan Tergugat diluar sidang dan dalam keterangannya Penggugat menyatakan bahwa Tergugat telah melunasi kewajibannya yang tertuang dalam perjanjian sejumlah Rp.6.943.000,00.-. 
4) Penggugat dengan alasan tersebut pada poin $\mathrm{c}$ mengajukan permohonan pencabutan perkara sederhana sengketa ekonomi syariah dengan alasan Tergugat telah melunasi kewajibannya. Berdasarkan hal tersebut Hakim menjatuhkan penetapan dengan mengabulkan permohonan pencabutan perkara yang diajukan oleh Penggugat.

Berdasarkan uraian di atas, maka menurut pendapat Penulis bahwa Hakim Pengadilan Agama Kediri telah menyelesaikan perkara sederhana sengketa ekonomi syariah melalui tahapan persidangan yang tepat dan sesuai dengan ketentuan hukum acara yang berlaku.

\section{KESIMPULAN}

1. Bahwa perdamaian yang terjadi antara kedua pihak yang bersengketa terhadap perkara sederhana sengketa ekonomi syariah di Pengadilan Agama Kediri tidak didasarkan atas putusan Hakim dalam bentuk akta perdamaian, dikarenakan antara Penggugat dan Tergugat telah terjadi perdamaian diluar persidangan, perdamaian yang terjadi diluar persidangan tersebut di sampaikan atas keterangan sepihak dari Penggugat di depan persidangan tanpa hadirnya Tergugat, sehingga dengan demikian hakim tidak terikat dengan perdamaian tersebut. Oleh karena sejak awal persidangan berlangsung Tergugat tidak pernah hadir di dalam persidangan, maka permohonan pencabutan perkara yang diajukan oleh Penggugat dapat dikabulkan tanpa harus mendapatkan persetujuan dari pihak Tergugat, hal ini sudah sesuai dengan isi buku II tentang Pedoman Pelaksanaan Tugas dan Administrasi Peradilan Agama. Dan maka dari itu sesuai permohonan pencabutan perkara yang diajukan Penggugat, selanjutnya Hakim memutus perkara ini dalam bentuk penetapan yang isi pokoknya mengabulkan permohonan Penggugat untuk mencabut perkara nomor 0191/Pdt.G/2019/PA. Kdr.

2. Proses persidangan perkara sederhana sengketa ekonomi syariah di Pengadilan Agama Kediri dari tahap awal pendaftaran, pemeriksaan kelengkapan gugatan sederhana, menetapkan panjar biaya perkara, pemeriksaan pendahuluan, penetapan hari sidang dan pemanggilan para pihak, pemeriksaan sidang hingga dijatuhkannya penetapan oleh Hakim tunggal dibantu Panitera Pengganti yang didasarkan atas pencabutan oleh pihak Penggugat dengan alasan telah terjadi perdamaian dengan Tergugat diluar persidangan telah sesuai dengan ketentuan hukum acara yang berlaku. 


\section{DAFTAR PUSTAKA}

Varia Peradilan, 2018, Penyelesaian Sengketa Ekonomi Syariah Melalui Gugatan Sederhana (Implementasi dan Permasalahan), Majalah Hukum Tahun XXXIV No. 395, Oktober, Jakarta, hlm 44

Ali, Achmad, 2004, Sosiologi Hukum Kajian Empiris Terhadap Pengadilan, STIH IBLAM, Jakarta.

Anshori, Abdul Ghofur, 2010, Penyelesaian Sengketa Perbankan Syariah (Analisis Konsep dan UU No 21 Tahun 2008), Gadjah Mada University Press, Yogyakarta.

Antonio, Muhammad Syafii, 2001, Bank Syariah dari Teori ke Praktik, Gema Insani, Jakarta.

Ash-Shofa, Burhan, 2004, Metode Penelitian Hukum, PT. Rineka Cipta, Cetakan Keempat, Jakarta.

Dewi, Gemala, 2007, LLM, Hukum Perikatan Islam di Indonesia, Kencana, Jakarta.

Fakhriah, Efa Laela, 2012, Penemuan Hukum oleh Hakim Melalui Pembuktian dalam

Penyelesaian Sengketa Perdata dengan Menggunakan Bukti Elektronik, Universitas Padjajaran, Bandung.

Harahap, M. Yahya, 1986, Segi-Segi Hukum Perjanjian, Alumni, Bandung.

Witanto, 2017, Gugatan Sederhana Teori, Praktik, dan Permasalahannya, Pustaka Dunia, Jakarta.

Marzuki, Peter Mahmud, 2005, Penelitian Hukum, Kencana, Jakarta.

Narbuko, Cholid dan Abu Achmadi, 1997, Metodologi Penelitian, Bumi Pustaka, Jakarta.

Nuruddin, Amiur, 2010, Penyelesaian Sengketa Ekonomi Syariah dalam Perspektif Islam.

Ramli, Hasbi, 2005, Teori Dasar Akuntansi Syariah, Renaisan, Jakarta.

Satrio, J, 1995, Hukum Perikatan, Perikatan Yang Lahir Dari Perjanjian, Buku I, 